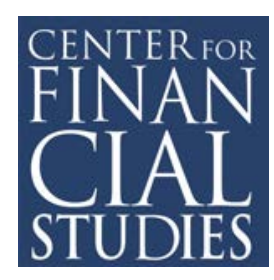

CFS WORKING PAPER

No. $2013 / 02$

A New Paradigm for Monetary Policy?

Otmar Issing 


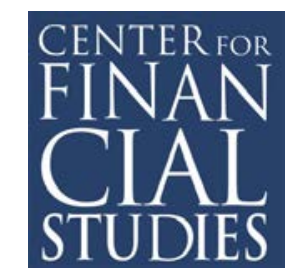

\section{CFS Working Paper Series}

The Center for Financial Studies, located in Goethe University's House of Finance in Frankfurt, is an independent non-profit research center, funded by the non-profitmaking organisation Gesellschaft für Kapitalmarktforschung e.V. (GfK). The CFS is financed by donations and by contributions of the GfK members, as well as by national and international research grants. The GfK members comprise major players in Germany's financial industry. Established in 1967 and closely affiliated with the University of Frankfurt, it provides a strong link between the financial community and academia. CFS is also a contributor to policy debates and policy analyses, building upon relevant findings in its research areas.

The CFS Working Paper Series presents the result of scientific research on selected topics in the field of money, banking and finance. The authors were either participants in the Center's Research Fellow Program or members of one of the Center's Research Projects.

If you would like to know more about the Center for Financial Studies, please let us know of your interest.

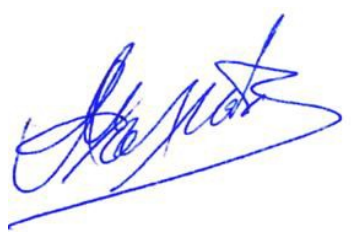

Prof. Michalis Haliassos, Ph.D.
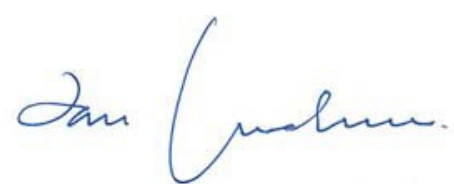

Prof. Dr. Jan Pieter Krahnen

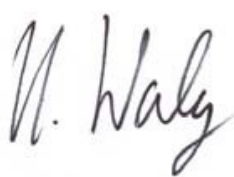

Prof. Dr. Uwe Walz 


\title{
A New Paradigm for Monetary Policy?*
}

\author{
Otmar Issing \\ Center for Financial Studies
}

Keynote speech to Conference

"Twenty Years of Transition - Experiences and Challenges"

Central Bank of Slovakia

Bratislava, 3 May 2013

* I would like to thank Francesco Drudi, Marvin Goodfriend, Florian Hense, Heinz Herrmann, Allan Meltzer, Massimo Rostagno, and John Taylor for valuable comments. 
$\underline{\text { Index }}$

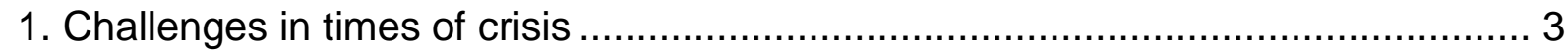

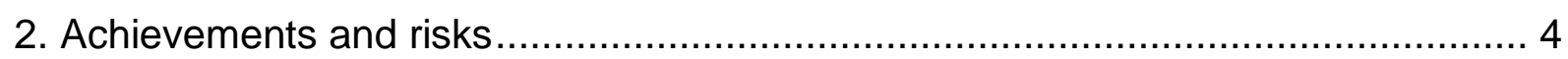

3. Time inconsistency, commitment and communication................................. 6

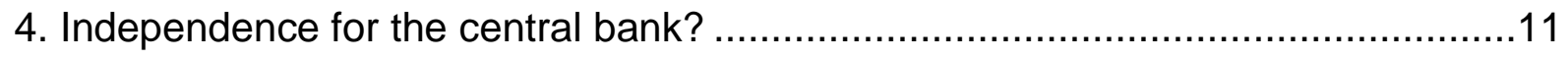

5. New paradigm or recollection of proven principles? ...................................15 


\section{Challenges in times of crisis}

The development of monetary theory and monetary policy over time reflects the interaction between central banks, the political and financial system, and research. ${ }^{1}$ "[T]he choice of measure of value, of a monetary system, of currency and credit legislation - all are in the hands of society ... Here, then, the rulers of society have an opportunity of showing their economic wisdom - or folly. Monetary history reveals the fact that folly has frequently been paramount; for it describes many fateful mistakes" (Wicksell, 1906, p. 314). Times of crisis present a special challenge. The financial crisis starting in 2007 unavoidably triggered memories of the Great Depression and its dire economic, political and social consequences. From the many studies on that period, the clear message that emerged was: the follies of that time must be avoided, and the world must be saved from a repetition of that disaster. As a result, all major central banks reduced their interest rates to exceptionally low levels. In fact, the expansionary monetary policy was extended beyond the zero bound by also implementing several kinds of so-called "unorthodox" measures. At the same time, a broad discussion has started on a number of issues:

- What are the achievements of these policies? What are the risks? How long should the period of extremely expansionary policy last? (Section 2)

- Should central banks change their strategies? (Section 3)

o Do we need a new paradigm for the conduct of monetary policy?

o What should central banks' mandate be?

o What is the role of central banks in the area of financial stability?

- Do we need a new institutional arrangement for central banks? What about their independent status? (Section 4)

\footnotetext{
${ }^{1}$ For a discussion on developments in Germany, see Issing and Wieland (2013).
} 


\section{Achievements and risks}

The timely reaction of monetary policy to the crisis in 2008 prevented the collapse and deep problems of financial institutions from plunging the real economy into a situation like that of the 1930s. True, output fell and unemployment increased sharply in many countries. Nowhere, however, did the negative outcome reach the dimension of the Great Depression. (In terms of unemployment and recession, some countries of the euro area come close to that experience - but for a different reason.)

Central banks have learned from the past and thus avoided the mistakes of their predecessors. One could indeed hardly imagine that they would not have learnt this lesson. However, while this reaction was extremely important, from a longer-term perspective it represents the easier part.

Approaching the zero bound for interest rate policy, central banks have expanded their balance sheets via measures termed "unorthodox" because they were not adopted before. While the policies applied had different forms, the overall macroeconomic goal was to stimulate the economy by lowering market interest rates. $^{2}$ Whereas the initial programs of quantitative easing presumably had a substantial impact on lowering long-term interest rates there exists wide disagreement on the durability of this effect and the consequences of the continuation of this policy (Martin and Milas 2012). Uncertainty about the longer-run effect is, of course, even greater and, thus, makes an assessment of the overall benefits and costs of these policies at this stage anything but easy (Bernanke 2012).

The fundamental critique of the Fed's unorthodox policy by Allan Meltzer (2012) stresses the short-term orientation based on shaky data, reliance on the Phillips curve and disregard for money, credit and asset prices, i.e. conducting a purely discretionary policy. This is also the main point of criticism of John Taylor (2012).

Two more aspects are also relevant. One is the potential undermining of fiscal discipline, and the other is the redistributive or rather discriminatory effects of

\footnotetext{
${ }^{2}$ The specific measures adopted by the ECB were different in nature insofar as they were aimed at supporting the transmission mechanism by stabilizing the banking system.
} 
purchasing specific assets. These are general problems that go along with quantitative easing.

Changing the course of monetary policy is always a difficult task: not too late - not too early, in small steps or with a decisive move? However, exit from unorthodox measures is a daunting challenge for several reasons. In the context of the zero bound it is very difficult to calculate the monetary policy stance and the impact of any changes - withdrawing liquidity and/or raising interest rates? How will markets react? When the central bank starts selling assets, is this not a signal to private agents to sell their assets outright before asset prices plummet? If the central bank tries to smooth this process - probably also under pressure from fiscal authorities - will this not be seen as accepting the emergence of inflationary pressures with consequences for inflation expectations, thereby causing even stronger increases in longer-term interest rates?

This process is complicated by the fact that a period of extremely low interest rates contributes to higher risk-taking, masks underlying weaknesses in balance sheets and prevents restructuring of the financial sector (Borio 2012). The impact on savings and insurance companies over time might become dramatic. The whole process of allocation of capital is heavily distorted. These undesirable medium-term effects are the unintended consequences of ultra-easy monetary policies (White 2012).

An extended period of very low interest rates makes the financial sector more and more vulnerable to a change of regime. The central bank will have to consider these risks of getting out of the zero bound and unorthodox measures. Extremely low interest rates also have an effect on government. They are hardly conducive to fiscal discipline. And huge stocks of government bonds expose the central bank to economic risks and political pressure. Paradoxical as it seems, the very consequence of large unorthodox measures by central banks could be to contribute to or even create a situation of fiscal dominance (Sargent and Wallace 1981).

Altogether, monetary policy might be "cornered" by the financial sector and fiscal authorities (Brunnermeier and Sannikov 2012).

These are strong arguments for being concerned about an extended period of extremely low interest rates. Under these circumstances, when should the central 
bank consider raising interest rates? The answer depends crucially on the assessment of the economic situation and implicit risks to price stability.

Where economic problems are caused by a collapse of financial markets, the result is much different from a "normal" cyclical downturn (Reinhart and Rogoff 2003). If economic problems are not of a monetary nature (Meltzer 2012), there is certainly no argument for further quantitative easing. Given the situation as of today, the case for ending the period of zero interest rates becomes more and more relevant (Taylor 2013).

\section{$\underline{\text { 3. Time inconsistency, commitment and communication }}$}

Central banks have reacted to the crisis with manifold ad hoc measures. A vast literature on time inconsistency problems (Kydland and Prescott 1977) and credibility as well as experience with policy give a strong warning that pure discretion will lead to uncertainty and volatility. One attempt to overcome this situation and to anchor expectations is by the use of "forward guidance" as a policy tool. Bernanke (2012, p.9) has explained that this "is not an unconditional promise", but rather, "a statement about the FOMC's collective judgment regarding the path of policy that is likely to prove appropriate, given the Committee's objectives and its outlook for the economy". On the other hand, the Committee announced its intention "to continue buying MBS and other assets until it sees a substantial improvement in the outlook for the labor market", "stated that it expects a highly accommodative stance of monetary policy to remain appropriate for a considerable time after the economic recovery strengthens" and "that it currently expects to hold the federal funds rate at exceptionally low levels at least through mid-2015..." (Yellen 2012, p.2).

However, the fundamental problem lies in this approach itself. Forward guidance suffers from the same sort of time inconsistency malaise it intends to remedy. Saying that the policy rate is likely to be low well into the future does not imply that the central bank, from the perspective of a future date and in the face of rising inflation, will have the incentive to follow through on its commitment. The reason being that at 
this moment in the future it will be confronted with all the costs associated with keeping its promise while the benefits will have been reaped in the past. In fact, this forward guidance is very prone to time inconsistency. The credibility of the forward guidance approach suffers severely from the fact that communication of the horizon for forward guidance has changed many times. From the FOMC's original statement "The Committee currently anticipates that economic conditions are likely to warrant exceptionally low levels for the federal funds rate for "some time" (December 2008), they moved to "an extended period" in March 2009. On 9 August 2011, the phrase was replaced by "at least through mid-2013" (the first time that a date was mentioned, the so-called date-based forward guidance). In January 2012, the endpoint was extended to "late 2014" and in September to "through mid-2015". In December came a move from date-based to outcome-based forward guidance: "at least as long as the unemployment rate remains above $61 / 2$ percent, inflation between one and two years ahead is projected to be no more than a half point above the Committee's 2 percent longer-run goal, and longer-term inflation expectations continue to be well anchored". It is, indeed a daunting challenge to make this guidance "understood and believed by the public" (Yellen 2012, p.7).

Assessing the relative impact of asset purchases and the policy stance expressed by the federal funds rate will be anything but easy for the central bank itself. How can the public understand this? What about changes in the composition of the FOMC?

Over such an extended period of time it is extremely difficult to forecast the impact of the announced monetary policy on the economy. New shocks might hit the economy. The time dimension of those developments varies with the type and magnitude of shocks, the prevailing financial sentiment, the international environment and many other variables. Is it therefore not impossible to set the horizon for monetary policy in advance (Issing 2002)? Credible forward guidance, and thereby the anchoring of public expectations, cannot come from announcing a fixed number for a policy rate but from providing a strategy which allows the public a kind of ex-ante understanding of policy decisions under varying conditions by the central bank. Announcing a specific number for the policy instrument, the main interest rate, for an extended period of time might be seen as an unconditional commitment, which carries the risk that any change will be interpreted as a surprise, with the potential to cause 
turbulence in markets and hurt the credibility of the central bank. On the other hand, "conditionality" of such an announcement might in the end give no forward guidance at all. There is even the risk that a kind of implicit pessimism about future growth might have an adverse effect (Woodford 2012).

It is not surprising that the end of inflation targeting as the "state of the art approach" has triggered a discussion about other concepts.

Announcing a nominal GDP target path is one of them. This should fulfill two conditions. It must allow for identifying the exit from a policy which keeps the interest rate at the lower bound as long as GDP remains below target. When this level is reached the central bank will raise the interest rate to the level that is needed to maintain nominal GDP growth around a steady growth path.

GDP (or rather GNP) targeting had its heyday in the nineteen-eighties (e.g. Ben McCallum 1988). However, this strategy was never adopted, in spite of "some theoretical appeal" (Kahn 1988). GDP growth cannot be controlled directly. As a result, McCallum (1988, p.176) proposed adopting the monetary base as a variable that the central bank can accurately set day-to-day. The advantage of a GDP target over a target for money lies in the implicit reaction to changes in velocity.

A strategy which relies on the interest rate as the control variable must be based on a model forecast. ${ }^{3}$ In the case of forward guidance, this has to be achieved over an extended period of time. Is it surprising that central banks resisted adopting a policy procedure that depends so explicitly and openly on fallible forecasts (Kahn 1988, p. 35)? This has hardly changed since then. Data on GDP come with lags and are subject to substantial revisions. It is also hardly convincing that such a strategy would be understood by the public. The message for the public might be that price stability (or low and stable inflation) for an extended period of time is of secondary importance or is even being sacrificed for stimulating the economy. Such an unanchoring of inflation expectations could have serious consequences. Rising inflation expectations might lead to higher long term interest rates, thereby producing the opposite effect to

\footnotetext{
${ }^{3}$ A rising number of publications discuss the pros and cons of the three different approaches to the path of future key interest rates in forecasts - unchanged, market expectations, and expectations of the central bank itself. A new paper by Knueppel and Schultefrankenfeld (2013) concludes that this is empirically irrelevant for the forecast accuracy. Therefore, it might be challenging for the central bank to shape private-sector forecasts by publishing unconditional forecasts.
} 
that intended. And we know from the past how costly in macro terms it is to bring the inflation rate (and corresponding expectations) back to a low level and restore the credibility of the central bank.

Central bankers now regularly stress the fact that inflation expectations are firmly anchored at low levels. All kinds of measures, be it break-even inflation rates over various time horizons, inflation-linked swap contracts, or surveys, seem to support this belief. However, is there not the risk that, after such an extended period, low inflation expectations in a backward-looking way are just reflecting the notion that this regime will continue? Consequently, the situation might be rather fragile and exposed to abrupt upward shifts once doubts about the orientation of central banks arise.

Concepts like the aforementioned seem to forget how problematic, and even dangerous, it is to rely on data for potential growth, the output gap or the NAIRU. The severity of this crisis is obviously used as an argument for ignoring such warnings, yet the misleading character of real-time output data is well known. Orphanides and Wieland (2013) demonstrate that relying on monetary aggregates helped the ECB to avoid this trap. However, the different nature of this "balance sheet recession" might even strengthen such warnings. Reinhart and Rogoff (2003) have argued that it takes much longer than after a "normal" recession for the economy to recover on a sustainable basis. A policy which ignores this might lead to severe mistakes.

Finally, what about the risks of GDP targeting - or any other approach of longer-term forward guidance - assuming Robert Gordon's (2012) warning that the US has to expect lower growth for decades (for reasons not related to the financial market crisis) is of relevance? (See also Council of Economic Advisers 2013; Deutsche Bundesbank 2013)

This brings us back to the fundamental question of what monetary policy can do and what it cannot do. In his famous presidential address, Milton Friedman (1968) argued that the central bank can control only nominal, but not real variables and should not target the rate of unemployment or employment. Is this conclusion now discarded? There still seems to be a widespread consensus that in the long run there is no tradeoff between unemployment and inflation and that inflation is determined by monetary policy (King 2005; Yellen 2012). 
However, two consequences then seem rather obvious. First, if the central bank promises more than it can possibly achieve, its reputation over time will suffer severely. Secondly, how convincing is any strategy for monetary policy which does not include an assessment of risks to price stability stemming from monetary developments? The perseverance of ignoring an active role for money and credit in concepts widely seen as state of the art is as striking as the neglect of studies which demonstrate the importance of monetary developments (e.g. Papademos and Stark 2010). Monetary developments are a kind of summary indicator of asset price developments (Meltzer 2012). A thorough analysis of monetary aggregates considering also e.g. the old concept of inside versus outside money can deliver valuable information on risks emerging in the banking sector (Kim, Shin and Yun 2013). Money and credit - more than real variables - contain information for signaling asset price booms which later might turn out to become very costly (Alessi and Detken 2009). Hence, a central bank which integrates the analysis of monetary developments into its strategy will have a compass for how to deliver its best contribution to preserving financial stability, too. In the first place macroprudential policy should take care of financial stability, and the success of this policy would reduce the pressure on monetary policy. However, an encompassing strategy would protect monetary policy from getting into conflict with its goal to maintain price stability (Issing 2003). Recent experience confirms the validity of the ECB's decision on its strategy incorporating developments in money and credit (ECB 2012). What should we infer from the fact that the ECB is (still?) the only major central bank in the world which seems to have a convincing answer to this challenge?

This is a strong - albeit not the only - argument against international coordination of monetary policy. There is no disagreement that cross-border flows may have an important impact on domestic monetary and credit aggregates (and vice versa). Yet, this makes the task of maintaining price stability (and preserving financial stability) for domestic policy more complex, but not impossible (ECB 2012). The idea that major central banks should internalize the spillover effects of their policies by creating an "International Monetary Policy Committee" that will "report regularly to world leaders on the aggregate consequences of individual central bank policies" (Committee 2011) lacks any convincing theoretical basis (Issing 2012). Agreeing on a possibly wrong model for monetary policy could only end in disaster. However, the negative 
international spillover effects of "independent" national discretionary monetary policies could also be severe.

\section{Independence for the central bank?}

In the meantime the worldwide discussion on the need for a new monetary policy regime has been extended to the question of the appropriate institutional arrangement. The case for independence seemed settled with the experience that inflation correlates negatively with the degree of independence of the central bank. A huge literature had delivered convincing evidence (see e.g. Cukierman 1992; Alesina and Summers 1993). As was demonstrated by a global movement to give central banks independence, practice followed theory. This consensus seems to be evaporating, as was expressed e.g. in a laconic statement by John Taylor (2013, p. 15): "It appears that existing law about independence has not worked." This remark was directed towards the Fed, but his argument is of a general nature. At the same annual meeting of the American Economic Association, Allan Meltzer (2012, p. 3) even asked: "Can independence [of the Fed, O.I.] be restored?"

What is the reason for this new discussion? In the context of the so-called "great moderation" inflation seemed to have confirmed the connection between independence and price stability. Figures for inflation continue to be on the low side. So, what has stirred this debate?

Within present institutional arrangements, i.e. representing de jure independence, it is the politics of central banks which meet with criticism. John Taylor (2013, p. 15) sees a loss of de facto independence, and argues that it is driven by the Fed itself. In this context the fundamental skepticism of classical liberals resurfaces. "A central bank which is not required to redeem its notes against cash has a wonderful life; it can lend what it likes and spend what it wants without having to fear harm to itself and without any significant limitations except its own inclination" (Bagehot 1873/1999, p. 111). Classical liberals are deeply concerned by this "concentrated power" of 
central bankers and ask for a "government of law instead of men" (Friedman 1962, p. 219 and p. 239). "Rules instead of Authorities" (Simons 1936) is the message.

To exclude any discretionary influence of individuals on monetary policy, observance of a strict rule would be required. However, strict rules, take e.g. Milton Friedman's kpercentage-rule, did not stand the test in theory and have no support anymore. On the other hand, pure discretion has also been discarded as a policy which exposes markets and actors to a maximum of uncertainty (for a thorough discussion, see Taylor 1999).

When the extremes of following a strict rule and pure discretion are excluded, the distinction between rules and discretion becomes a matter of degree (Taylor 2012). The ECB's monetary policy strategy can be seen as a rule-governed or rule-based commitment (ECB 2001).

"Rules with discretion" seems to be a rather vague concept. This is, however, not the case once the basic idea is respected that the rule should be the compass and deviations from the rule have to be explained (Meltzer 2012). The policy of the Deutsche Bundesbank was an example of such an approach. Whereas the central bank missed its target roughly half of the time, the target had nevertheless a disciplining effect as the bank had to justify deviations from target (Issing 1997). "Even if it is true that the reputation of the Bundesbank ultimately was achieved by its success in fulfilling its mandate to safeguard the stability of its currency, its final goal, current policy continuously had to be justified in the context of its pre-announced strategy. In this sense, the strategy contributed to the transparency, the accountability, and the credibility of the Bundesbank's policy" (Issing 2005, p. 50). The Bundesbank's monetary targeting can be interpreted as a commitment device (Beyer et al. 2008).

A rule-based monetary policy facilitates transparency and makes it clear that accountability is related to the achievement of the final goal. Independence from political influence allows the central bank to take the appropriate monetary policy decisions. For an independent central bank with a clear mandate to maintain price stability, accountability is restricted to a "technocratic" task. Thus the central bank does not need to "justify" measures taken to preserve price stability. Quite different from "justification" is the challenge of explaining why other goals like growth and 
employment are not neglected by conducting such a policy. This was e.g. the message conveyed by representatives of the ECB time and again to the European Parliament; the mandate itself is enshrined in the Treaty and cannot be revoked by parliamentary vote. This would be in total contradiction to the fundamental idea of "depoliticizing" monetary policy by making the central bank independent.

This idea was formulated in full clarity by the former UK Chancellor of the Exchequer Gordon Brown in 1997: "The previous arrangements for monetary policy were too short-termist, encouraging short but unsustainable booms and higher inflation, followed inevitably by recession. This is why we promised in our election manifesto to ... reform the Bank of England to ensure that decision-making on monetary policy is more effective, open, accountable and free from short-term political manipulation."

If in the longer run there is no trade-off between price stability and goals like employment or growth, and considering that the effects of monetary policy decisions have a rather long time-lag, a single mandate - price stability - is the logical consequence. A dual - or even triple etc. - mandate blurs the final possibilities and therefore responsibility of the central bank. The government will always give priority to fighting unemployment and implicitly have a bias for short-termism. Under such an arrangement a central bank voluntarily or under political pressure is always tempted to embark on a more expansionary monetary policy. ${ }^{4}$

This is behind the distinction between "de jure" and "de facto" independence (see e.g. Cargill and O'Driscoll 2012). If the central bank's independent status is exposed to strong political opposition, giving up independence de facto might be seen as an option to preserve de jure independence. However, this would come at the expense of undermining the fundament of independence for the central bank.

The decision to make the central bank independent is a deliberate act of "selfdeprivation of power", and by agreeing on such an arrangement parliament so to speak protects itself against itself (Issing 1993, p. 35). By its own logic this transfer of power excludes policies which need political approval. This is needed for all decisions with the objective of redistributing wealth. In a democracy such acts must be subject to parliamentary control. It is true that monetary policy unavoidably will

\footnotetext{
${ }^{4}$ In his great work on the history of the Fed, Allan Meltzer (2003, 2009) presents cases or rather periods when the central bank "coordinated" its policy with that of the government, thereby embarking on fine-tuning.
} 
have distributional effects. However, one of the strongest arguments for price stability is that inflation hurts those most that are unable to protect themselves against its consequences - i.e. the weakest groups in society. In any case, a central bank must abstain from measures which are directed to have distributional effects, like giving cheap credit to special groups and not to others. Redistributive monetary policy is a complex concept (see Brunnermeier and Sannikov 2012). A central bank which is embarking on such a course will have to explain or rather justify its decisions in political fora and cannot refer to "immunity" based on its independent status. This is probably even more true if a central bank in the context of its responsibility for bank supervision has the task and power to save or close a bank. This implies that the supervisor, i.e. the central bank, will be heavily involved in the actions of fiscal authorities as providers of taxpayers' money, which could result in political pressure jeopardizing the central bank's independence (de Larosière 2009, p. 43).

As long as there is no absolute (and absolutely convincing) strict rule, the people and personalities in charge will matter. Besides overcoming time inconsistency problems and anchoring inflation expectations at the desired low level, there is an argument in favor of appointing "conservative" central bankers, i.e. persons with a strong priority for price stability (Rogoff 1985). Divergent preferences of politics might lead to the choice of a "progressive" central banker in the sense that the person shares priorities of the government that give less attention to price stability. As Karl Popper put it: "Not only does the construction of institutions involve important personal decisions, but the functioning of even the best institutions ... will always depend, to a considerable degree, on the persons involved. Institutions are like fortresses. They must be well designed and manned" (Popper 1957, p. 66).

Central bank independence is always under threat. From inside (de facto), from outside in legal terms (de jure), and via appointments. The central bank is an institution of and within society. In extreme situations such as the insolvency of the state or a total collapse of the financial system, the central bank might lose "strategic independence", which means nothing less than that principles of sound monetary policy are put aside. ${ }^{5}$

\footnotetext{
${ }^{5}$ The case that the Reichsbank was independent in a time of hyperinflation in Germany in 1922/23 is sometimes used as an argument that independence is no protection against the destruction of the currency. The bank has to
} 
It does not come as a surprise that preferences in government, parliament, and the wider public for independence might change over time (Goodfriend 2012 calls it an "elusive promise"). A central bank can defend its independent status only to the extent that it delivers on its mandate, communicating its policy to the public in a transparent and coherent way - but also by abstaining from all measures which imply "de facto" dependence. Beyond that the status of independence - de jure and de facto - is exposed to changes in preferences of politics and society. "Not even an independent central bank can lastingly defend monetary stability against a 'society of excessive demands' - in other words, every society gets the rate of inflation it deserves and basically wants" (Issing 1993, p. 36). However, this is not an argument for the central bank to "surrender" by giving up de facto independence.

\section{New paradigm or recollection of proven principles?}

A broad consensus had emerged that price stability, sometimes defined as low and stable inflation, must be the top priority for monetary policy, that the independence (de jure and de facto) of the central bank was an indispensable prerequisite, and that inflation targeting was the optimal strategy for achieving this goal. There are indications that this consensus does not exist any more or is at least being disputed.

Greater flexibility and tolerance for inflation, closer coordination with fiscal policy at home and internationally with other central banks, and a broader mandate including financial stability are the main arguments for a reorientation of monetary policy. The crisis - its causes and its consequences - has demonstrated that inflation targeting as the dominating concept has failed. All attempts at "rescue" have ended in a more or less meaningless approach (Issing 2011).

In light of that, one might ask for a new paradigm for the conduct of monetary policy. But, learning the right lesson would bring us rather to a recollection of lost or ignored principles. The new debate on the status of central banks demonstrates that the

be criticized for a very odd understanding (or rather misunderstanding) of monetary developments. On the other hand, the situation in Germany after the loss of the war was in many respects out of control (James 1999). 
consequences of "rules versus discretion" should be reconsidered and the independence of the central bank should be preserved via a single mandate and corresponding behavior of the central bank. How long will we have to wait until the neglect of money and credit in monetary (!) theory and policy will be understood as the major source of macro policy mistakes? Is it not strange, to say the least, that in a world in which money, credit and financial markets play a fundamental role models which give these variables hardly any active role are still dominant (see e.g Congdon 2011)? And, how many speeches and papers by central bankers are presented in which the term "money" or "credit" was not even mentioned? Considering the developments that have taken place over the decades, one should expect that the time of "monetary" macroeconomics and "monetary" policy without "money and credit" will come to an end. Hopefully, this will happen before a new and probably even deeper crisis sets in. 


\section{Bibliography}

Alesina, Alberto and Summers, Larry (1993), "Central Bank Independence and Macroeconomic Performance: Some Comparative Evidence, Journal of Money, Credit and Banking, May.

Alessi, Lucia and Detken, Carsten (2009), 'Real Time' early warning Indicators for costly Asset Price Boom/Bust Cycles: A Role for Global Liquidity, ECB, Working Paper Series No. 1039, March.

Bagehot, Walter (1873/1999), Lombard Street, New York.

Bernanke, Ben S. (2012), Monetary Policy since the Outset of the Crisis, Jackson Hole, 31 August.

Beyer, Andreas, Gaspar, Vitor, Gerberding, Christina, Issing, Otmar (2008), Opting out of the Great Inflation: German Monetary Policy after the Break Down of Bretton Woods, NBER, Working Paper 14596, December.

Borio, Claudio (2012), "The Financial Cycle and Macroeconomics: What have we learnt?", BIS Working Paper No. 395, December.

Brunnermeier, Markus K. and Sannikov, Yuliy (2012), Redistributive Monetary Policy, Jackson Hole.

Cargill, Thomas F. and O'Driscoll, Gerald P. Jr. (2012), "Measuring Central Bank Independence, Policy Implications, and Federal Reserve Independence", American Economic Association Meeting, San Diego, January.

Committee on International Economic Policy and Reform (2011), Rethinking Central Banking, September.

Congdon. Tim (2011), Money in a Free Society, New York.

Council of Economic Advisers (2013), Economic Report of the President.

Cukierman, Alex (1992), Central Bank Strategies: Credibility and Independence, Cambridge.

De Larosière (Chairman) (2009), The High Level Group on Financial Supervision in the EU, Report, Brussels, 25 February.

Deutsche Bundesbank (2013), "Die US-Wirtschaft im aktuellen Konjunkturaufschwung" Monatsbericht, April.

European Central Bank (2001), "Issues related to Monetary Policy Rules", Monthly Bulletin, October, 37-50. 
European Central Bank (2012), "Global Liquidity: Concepts, Measurements and Implications for a Monetary Policy Perspective", Monthly Bulletin, October, 5568.

Friedman, Milton (1962), "Should there be an Independent Monetary Authority?", in: Leland B. Yeager (ed.), In Search of a Monetary Institution, Cambridge, Mass., 219-243.

Friedman, Milton (1968), "The Role of Monetary Policy", The American Economic Review, March, 1-17.

Goodfriend, Marvin (2012), "The Elusive Promise of Independent Central Banking", Bank of Japan, Monetary and Economic Studies, November, 39-54.

Gordon, Robert J. (2012), "Is U.S. Economic Growth Over? Faltering Innovation confronts the six Headwinds", Centre for Economic Policy Research, Policy Insight No. 63, September.

Issing, Otmar (1993), "Central Bank Independence and Monetary Stability", Institute of Economic Affairs, Occasional Paper 89, London.

Issing, Otmar (1997), "Monetary Targeting in Germany: The Stability of Monetary Policy and of the Monetary System", Journal of Monetary Economics, 39, 67-79.

Issing, Otmar (2002), "Monetary Policy in a Changing Environment", in: The Federal Reserve Bank of Kansas City, ed. Rethinking Stabilization Policy, 183-205.

Issing, Otmar (2003), "Monetary and Financial Stability: Is there a Trade-off?", Bank for International Settlements, March.

Issing, Otmar (2005), "Monetary Policy in Uncharted Territory", in: O. Issing, V. Gaspar, O. Tristani, and D. Vestin, Imperfect Knowledge and Monetary Policy, Cambridge, 12-76.

Issing, Otmar (2011), Lessons for Monetary Policy: What should the Consensus be?, IMF Working Paper 11/97.

Issing, Otmar (2012), "The Mayekawa Lecture: Central Banks - Paradise Lost", Bank of Japan, Monetary and Economic Studies, November, 55-74.

Issing, Otmar and Wieland, Volker (2013), "Monetary Theory and Monetary Policy. Reflections on the development over the last 150 years", Jahrbücher für Nationalökonomie und Statistik, Vol. 233/3, Stuttgart.

James, Harold (1999), "The Reichsbank 1876-1945", in: Deutsche Bundesbank (ed.), Fifty Years of the Deutsche Mark, Oxford, 3-53.

Kahn, George A. (1988), "Nominal GNP: An Anchor for Monetary Policy?", Federal Reserve Bank of Kansas City, Economic Review, November. 
Kim, Hyun J., Shin, Hyun S., Yun, Jaeho (2013), "Monetary Aggregates and the Central Bank's Financial Stability Mandate", International Journal of Central Banking, 9, Suppl. 1, 69-107.

King, Mervyn (2005), "Monetary Policy: Practice ahead of Theory", Mais Lecture.

Knueppel, Malte and Schultefrankenfeld (2013), The Empirical (Ir)Relevance of the Interest Rate Assumption for Central Bank Forecasts, Bundesbank Discussion Paper, Forthcoming.

Kydland, Finn E. and Prescott, Edward C. (1977), "Rules rather than Discretion: The Inconsistency of Optimal Plans", Journal of Political Economy, June.

McCallum, Bennett T. (1988), "The Role of Demand Management in the Maintenance of Full Employment", NBER Working Paper Series, Working Paper No. 2520, February.

Martin, Christopher, Milas, Costas (2012), "Quantitative easing: a skeptical view", Oxford review of economic policy, 4, 750-784.

Meltzer, Allan H. (2003), A History of the Federal Reserve, Vol. 1, 1913-1951, Chicago.

Meltzer, Allan H. (2009), A History of the Federal Reserve, Vol. 2, Book 2, 19701986, Chicago.

Meltzer, Allan H. (2012), "What's Wrong with the Fed: What would restore Independence?", July.

Orphanides, Athanasios, and Wieland, Volker (2013), "Complexity and Monetary Policy", International Journal of Central Banking, 9, Suppl. 1, 167-203.

Papademos, Lucas D. and Stark, Juergen, eds. (2010), Enhancing Monetary Analysis, European Central Bank, Frankfurt.

Popper, Karl (1957), The Open Society and Its Enemies, Vol. 1 The Spell of Plato, Chapter 7. The Principle of Leadership, 3rd ed., London.

Reinhart, Carmen and Rogoff, Ken (2003), This Time is Different: Eight Centuries of Financial Folly, Princeton.

Rogoff, Kenneth (1985), "The Optimal Commitment to an Intermediate Target", Quarterly Journal of Economics, November.

Sargent, Thomas J. and Wallace, Neil (1981), "Some Unpleasant Monetarist Arithmetic", Federal Reserve Bank of Minneapolis, Quarterly Review, Fall, 1-17.

Simons, M. (1936), "Rules versus Authority in Monetary Policy", Journal of Political Economy, February. 
Taylor, John B., ed. (1999), Monetary Policy Rules, Chicago.

Taylor, John B. (2007), "Housing and Monetary Policy", in Jackson Hole Symposium on Housing, Housing Finance, and Monetary Policy, The Federal Reserve Bank of Kansas City.

Taylor, John B. (2012), "Monetary Policy Rules work and Discretion doesn't: a Tale of two Eras", Journal of Money, Credit and Banking, 44, 6, 1017-1032.

Taylor, John B. (2013), "The Effectiveness of Central Bank Independence versus Policy Rules", American Economic Association Meeting, San Diego, January, 122.

White, William R. (2012), Ultra Easy Monetary Policy and the Law of Unintended Consequences, Federal Reserve Bank of Dallas, Globalization and Monetary Policy Institute, Working Paper No. 126, August.

Wicksell, Knut (1906), Lectures on Political Economy, Vol. 2: Money, London.

Woodford, Michael (2012), Methods of Policy Accommodation at the Interest-Rate Lower Bound, Jackson Hole, August.

Yellen, Janet L. (2012), "Revolution and Evolution in Central Bank Communication", Haas School of Business, November. 


\begin{tabular}{|c|c|c|}
\hline No. & Author(s) & Title \\
\hline 2013/01 & $\begin{array}{l}\text { Andrej Gill, Steffen } \\
\text { Juranek, Christian } \\
\text { Lizarazo, Nikolai Visnjic, } \\
\text { Uwe Walz }\end{array}$ & $\begin{array}{l}\text { Anreize, systemische Risiken und } \\
\text { Intransparenz. Lehren aus der Finanz- und } \\
\text { Staatsschuldenkrise }\end{array}$ \\
\hline $2012 / 20$ & $\begin{array}{l}\text { Otmar Issing } \\
\text { Volker Wieland }\end{array}$ & $\begin{array}{l}\text { Monetary Theory and Monetary Policy: } \\
\text { Reflections on the Development over the last } \\
150 \text { years }\end{array}$ \\
\hline 2012/19 & $\begin{array}{l}\text { Laura Moretti } \\
\text { Toru Suzuki }\end{array}$ & $\begin{array}{l}\text { Strategic Transparency and Electoral } \\
\text { Pressure }\end{array}$ \\
\hline 2012/18 & $\begin{array}{l}\text { Harold L. Cole } \\
\text { Soojin Kim } \\
\text { Dirk Krueger }\end{array}$ & Analyzing the Effects of Insuring Health Risks \\
\hline 2012/17 & $\begin{array}{l}\text { Carmen Lee } \\
\text { Roman KräussI } \\
\text { Leo Paas }\end{array}$ & $\begin{array}{l}\text { The Effect of Anticipated and Experienced } \\
\text { Regret and Pride on Investors' Future Selling } \\
\text { Decisions }\end{array}$ \\
\hline 2012/16 & $\begin{array}{l}\text { Roman Kräussl } \\
\text { Stefan Krause }\end{array}$ & $\begin{array}{l}\text { Has Europe Been Catching Up? An Industry } \\
\text { Level Analysis of Venture Capital Success } \\
\text { over 1985-2009 }\end{array}$ \\
\hline 2012/15 & $\begin{array}{l}\text { Robert Wuebker } \\
\text { William Schulze } \\
\text { Roman Kräussl }\end{array}$ & $\begin{array}{l}\text { Is Venture Capital a Local Business? A Test } \\
\text { of the Proximity and Local Network } \\
\text { Hypotheses }\end{array}$ \\
\hline 2012/14 & $\begin{array}{l}\text { Fabian Bornhorst } \\
\text { Ashoka Mody }\end{array}$ & Test of the German Resilience \\
\hline 2012/13 & $\begin{array}{l}\text { Adrian Alter } \\
\text { Andreas Beyer }\end{array}$ & $\begin{array}{l}\text { The Dynamics of Spillover Effects during the } \\
\text { European Sovereign Debt Turmoil }\end{array}$ \\
\hline 2012/12 & $\begin{array}{l}\text { John F. Cogan } \\
\text { John B. Taylor } \\
\text { Volker Wieland } \\
\text { Maik Wolters }\end{array}$ & Fiscal Consolidation Strategy \\
\hline
\end{tabular}

All CFS Working Papers can be downloaded at www.ifk-cfs.de/publications/working-papers. 